\title{
Emoticón en catéter
}

\section{Emoticon on a catheter}

María Paula Segui ${ }^{1}$

${ }^{1}$ Servicio de Diagnóstico por Imágenes, Hospital San Martín La Plata,

Address for correspondence M. P. Segui, Servicio de Diagnóstico por Imágenes, Hospital San Martín La Plata, Buenos Aires, Argentina

Rev Argent Radiol 2018;82:101.

(e-mail: mpsegui_89@hotmail.com).

El catéter doble $\mathrm{J}$ es utilizado en los trasplantes renales como una forma de prevenir complicaciones urológicas, especialmente las fístulas y estenosis ureterales. Se colocan durante dos o tres semanas y luego se retiran por cistoscopia.

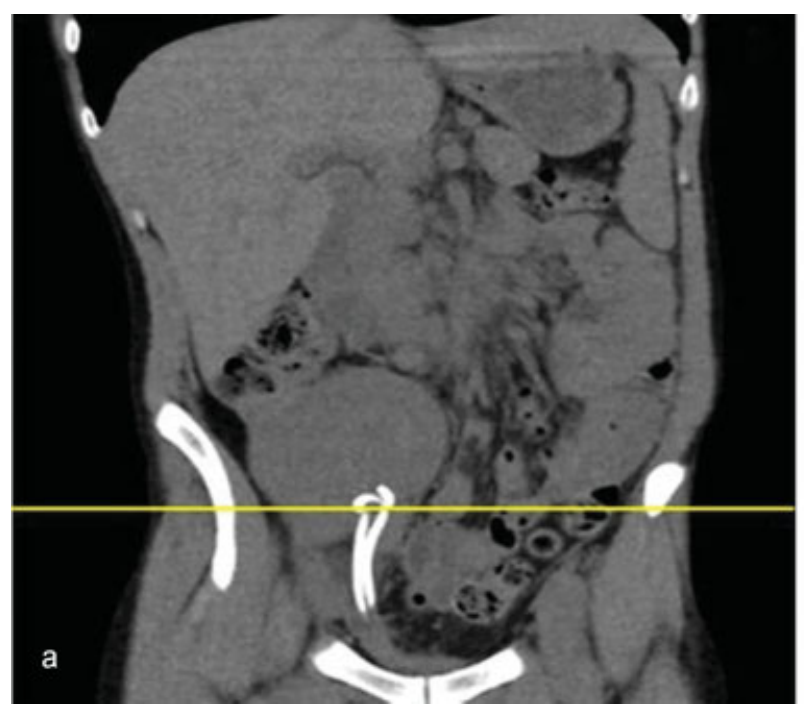

Mostramos un paciente recientemente trasplantado, con doble sistema excretor del injerto renal, que requirió la utilización de dos catéteres doble J (-Fig. 1) En la imagen axial la curvatura del extremo proximal de los catéteres nos recuerda un emoticón con cara feliz (-Fig. 2).

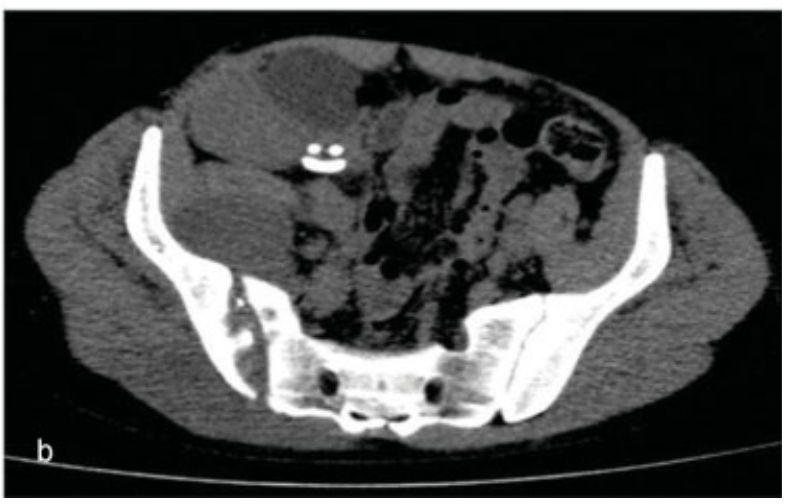

Fig. 1 Dos catéteres doble J.

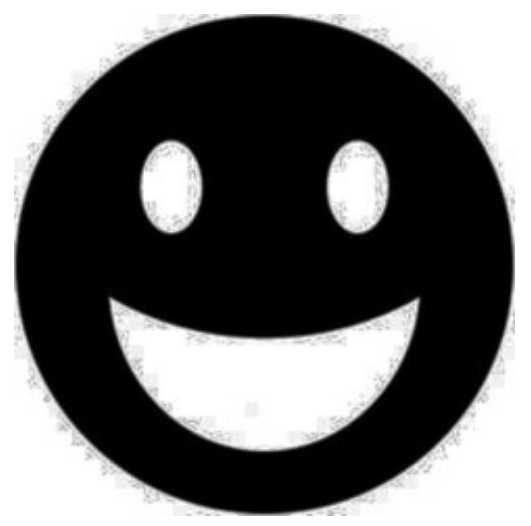

Fig. 2 Emoticón con cara feliz.

published online April 2, 2018
DOI https://doi.org/

10.1016/j.rard.2017.04.005. ISSN 1852-9992.
Copyright @ $\odot 2019$, Sociedad Argentina de Radiología. Publicado por Thieme Revinter Publicações Ltda., Rio de Janeiro, Brazil. Todos los derechos reservados.

\section{License terms}

(c) (1) $\ominus$ (5) 